ORIGINAL ARTICLE

\title{
The Prevalence of Antibiotic Resistant Diarrhogenic Bacterial Species in Surface Waters, South Eastern Nigeria
}

\author{
Stanley C. Onuoha ${ }^{1,2 *}$
}

\footnotetext{
OPEN ACCESS

Citation: Stanley C. Onuoha. The Prevalence of Antibiotic Resistant Diarrhogenic Bacterial Species in Surface Waters, South Eastern Nigeria. J Health Sci 2017;27(4):319. doi: http://dx.doi.org/10.4314/ejhs.v27i4.3

Received: February 5, 2017

Accepted February 8, 2017

Published: July 1, 2017

Copyright: (c) 2017 Stanley C.O. This is an open access article distributed under the terms of the Creative Commons Attribution License, which permits unrestricted use, distribution, and reproduction in any medium, provided the original author and source are credited. Funding: Nil

Competing Interests: The authors declare that this manuscript was approved by all authors in its form and that no competing interest exists.

Affiliation and Correspondence:

${ }^{1}$ Department of Biotechnology, Ebonyi State University, PMB 053 Abakaliki, Ebonyi State, Nigeria ${ }^{2}$ Microbial Ecology Laboratory, Arid Land Research Center, Tottori University, Tottori, Japan

*Email:sconuoha@yahoo.com
}

\begin{abstract}
BACKGROUND: This study assessed the bacteriological qualities of surface waters in Afikpo, between April and September 2016. METHODS: Surface water samples were collected from three streams for bacteriological analysis. Bacteria species were isolated using standard microbiological and biochemical techniques. Antibiotic susceptibility study was carried out using Kirby Bauer disc diffusion method.

RESULTS: The result of the mean heterotrophic bacteria count from the streams showed that Okpu stream had 209.5CFU/100 $\mathrm{mL}$, Ohino Ngodo $162.5 \mathrm{CFU} / 100 \mathrm{~mL}$, and Ngwogo stream 162.0 CFU/100mL respectively. Out of the twenty-six (26) isolates obtained, E. coli and Staphylococcus species had the highest percentage occurrence (23.1\%) respectively. Klebsiella, Shigella and Enterobacter sp had (11.5\%) each, Pseudomonas spp (7.7\%), while Salmonella and Streptococcus sp had the least percentage occurrence of (3.8\%). The antibiotic susceptibility studies showed that large proportions of isolates were resistant to sulphamethaxoid (SUL), cephalothin (CEP), tetracycline (TET), penicillin G (PEN), oxytetracycline $(\mathrm{OXY})$, cefotaxime $(\mathrm{CEF})$, nalidixic acid (NAL) and cefuroxime sodium (CXM). The most effective antibiotic was azithromycin followed by imipenem.

CONCLUSION: The presence of these multi-drug resistant strains in water samples could facilitate transmission of antibiotic resistance. This emphasizes the need for proper treatment of water in the study area.

KEYWORDS: Antibiotic resistance, Bacteria, Afikpo, Surface waters
\end{abstract}

\section{INTRODUCTION}

Water is considered a vehicle for the propagation and distribution of human associated bacteria (1). Safe drinking water is fundamental right and if it is contaminated with opportunistic pathogenic environmental bacteria, it may have health implication (2). Human health should be protected by preventing microbial contamination of water that is intended for consumption (3). In rural communities, untreated surface water from rivers, dams and stream is directly used for drinking and other domestic purposes (4). These unprotected

DOI: http://dx.doi.org/10.4314/ejhs.v27i4.3 
surface water can be contaminated with microbes through rainfall, runoff and agricultural input, mixing with sewage effluent and feces from wildlife $(5,6)$, which render it unacceptable for human consumption.

Antibiotics are a class of naturally-occurring, semi-synthetic and/or chemically synthesized compounds with antimicrobial activity. They are widely used in human and veterinary medicine to treat and prevent diseases and as growth promoters in animal intensive industries. The increasing incidence of resistance to a wide range of antibiotics by microorganisms is a major concern facing modern medicine. Clinical infections, disease and death caused by resistant bacteria are increasingly common. We know that antibiotic resistance can be established and propagated in human and animal digestive systems $(7,8)$. The proliferation of resistant strains within the gastrointestinal track is facilitated by the cooccurrence of high concentrations of bacteria and sub-lethal doses of antibiotics. However, there is some conjecture and speculation about other environments, such as sewage treatment plants (STPs) (9) and aquatic environments in general (10), which provide conducive conditions for the establishment and propagation of antibiotic resistant bacteria.

Diarrheal diseases are a global public health problem, causing significant morbidity and mortality among infants and children under five years particularly in the developing countries (11). Approximately, 2.6 million deaths occur each year, especially among children (12). Person to person transmission by direct or indirect contact, consumption of contaminated foods, drinking sewage-contaminated water and unpasteurized juice are the most common modes of obtaining the infections (12). Many cases are not identified, because they are minor and self-limiting; the patient does not seek medical care, or because, particularly in developing countries, the medical and laboratory resources are not accessible (13). Despite the various accessibility microbiological test, approximately half of the cases of diarrhea have no clear etiology, which confuses the application of strategies for mapping and monitoring endemic regions of the incidence of such pathogens (14). In view of the prevailing problem of portable water in Afikpo, the study was aimed to investigate diarrhogenic organisms and determine their susceptibility pattern to antibiotics.

\section{MATERIALS AND METHODS}

Description of study area: Afikpo, also known as 'Ehugbo' is a town and the second largest urban area in Ebonyi State, Nigeria. It is the headquarter of Afikpo North Local Government Area of Ebonyi State. It is bordered to the North by Akpoha, South by Unwana, South west by Edda in Afikpo South Local Government Area, to the East by Cross River and to the West by Amasiri. Afikpo spans an area approximately 164 square kilometers in size (Fig. 1). There are several streams located within the town, such as Okpu stream, Ohino-Ngodo stream and Ngwogo stream; they all run through the city and flow past the outskirts adjoining suburbs. The supply of municipal water is completely lacking in the city and its adjoining towns and communities. Most of the inhabitants therefore resort to the use of hand dug wells and streams as sources of water for drinking and other domestic purposes. The probability of contamination of the streams is high especially during the rainy seasons, from wastewater contaminations, from urban and rural run offs and agricultural activities as the streams flow through the city and its suburbs.

Sample collection and processing: Water samples were collected from three different sources namely: Ohino-Ngodo, Okpu and Ngwogo streams. The water was collected in the morning (between 8 - 11:59 am) in a sterile container which was drawn directly from the water. The samples were labeled properly and transported on ice to the laboratory for analysis. Aliquots of the samples were used for selective isolation of targeted bacteria based on standard microbiological procedures (15). 


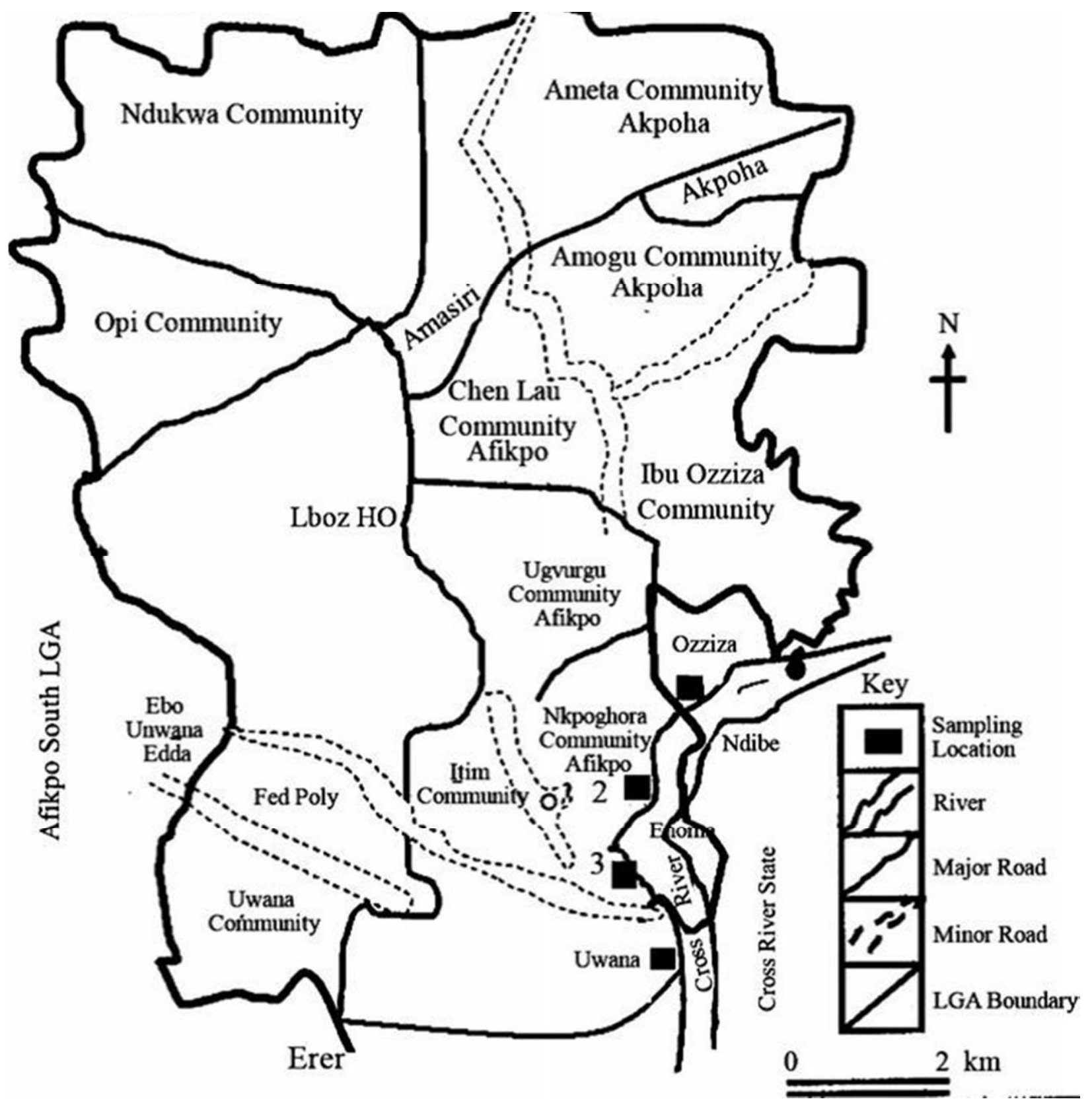

Figure 1: Map of Afikpo showing the sampling locations

Isolation, purification and characterization of planktonic bacteria: For all samples, three volumes of $100 \mathrm{~mL}$ were filtered through $0.45 \mu \mathrm{m}$ pore sized filter (Whatman Laboratory Division, Maidstone, England) using a water pump (model Sartorius 16824). The membrane was then placed on the plate containing nutrient media ensuring that no air bubbles were trapped. The plates were incubated at $37^{\circ} \mathrm{C}$ for 24 hours to observe growth, after which the number of colony was counted. The colonies were then sub-cultured into appropriate selective media such as SalmonellaShigella Agar (SSA) for the isolation of Salmonella and Shigella sp, Mannitol Salt Agar (MSA) for the isolation of Staphylococci, Eosin 
Methylene Blue (EMB) and McConkey Agar (MA) for the isolation of $E$. coli and other enterobacteriaceae. All media were obtained from Biolab, Merck, South Africa. The agar plates were incubated at $37^{\circ} \mathrm{C}$ for $18-24$ hours. All the bacterial isolates were identified based on their colony morphology, Gram's reaction, catalase test, motility test and biochemical tests such as oxidase test, citrate test, indole test, MethylredVogesProskauer (MRVP) test, urease test, hydrogen sulphide production test and sugar fermentation.

Disc diffusion susceptibility test: Bacteria isolates were subjected to in-vitro susceptibility test against commonly used antimicrobial agents using disk diffusion method following guidelines established by the Clinical and Laboratory Standards Institute (16). In brief, by taking pure isolated colony, bacterial suspension was adjusted to $0.5 \mathrm{McF}$ arl and turbidity standards. The diluted bacterial suspension was then transferred to Mueller-Hinton agar(Biolab, Merck, SA) plate using a sterile cotton swab and the plate was seeded uniformly by rubbing the swab against the entire agar surface followed by 24 hours' incubation. After the inoculums were dried, antibiotic impregnated disks were applied to the surface of the inoculated plates using sterile forceps. The plates were then incubated aerobically at $37{ }^{\circ} \mathrm{C}$ for 24 hours. Finally, the zone of inhibition was measured including the disk diameter. The susceptible and resistant categories were assigned on the basis of the critical points recommended by the CLSI and according to the manufacturer's leaflet attached to them. The standard antibiotic discs (Oxoid, England) and their concentrations used against the isolates were tetracycline (TET)-10 $\mu \mathrm{g}$, cephalothin (CEF)-30 $\mu \mathrm{g}$, norfloxacin (NOR)-10 $\mu \mathrm{g}$, penicillin $\mathrm{G}$ (PEN)$10 \mu \mathrm{g}$, azithromycin (AZM)-15 $\mu \mathrm{g}$, streptomycin (STR)-10 $\mu \mathrm{g}$, cephotaxime (CTX)-30 $\mu \mathrm{g}$, gentamycin (GEN)-30 $\mu \mathrm{g}$, imipenem (IPM)-10 $\mu \mathrm{g}$, cefpirome (CPO)-30 $\mu \mathrm{g}$, sulphonamides (SUL)$30 \mu \mathrm{g}$, nalidixic acid (NAL)-30 $\mu \mathrm{g}$, erythromycin (ERY)-10 $\mu \mathrm{g}$, oxytetracycline (OXY)-30 $\mu \mathrm{g}$, sulphamethoxazole (SMX) $-25 \mu \mathrm{g}$ and cefuroxime sodium (CXM)-30 $\mu \mathrm{g}$. These antibiotics were chosen because they are either used in both human medicine and animal veterinary practice or because previous studies have reported microbial resistance to them.

Multiple antibiotic resistance index (MARI): MARI values of isolated bacteria against the antibiotics used were computed. MARI is a tool that helps in analyzing health risks and checking antibiotic resistance in a given area. The value of MARI is 0.20 , and it differentiates the low risk $(<0.20)$ from the high risk $(>0.20)$. It is calculated by dividing the aggregate resistance of total isolates of an organism to all antibiotics by the product of the total number of antibiotics used and the number of isolates of an organism from the sample site. i.e. $\mathrm{x} /(\mathrm{y} . \mathrm{z})$, where $\mathrm{x}$ represents the aggregate resistance of total isolates of an organism to all antibiotics, y represents the total number of antibiotics used and $\mathrm{z}$ stand for the number of isolates of an organism from the sample site. This formula was used since the MARI was being calculated from a sample site (environmental sampling) where many isolates were obtained according to the method of Riaz et al., (17).

\section{RESULTS}

Total bacterial count: The result of the mean heterotrophic count of the bacteria isolated from the three water sources are presented in Table 1. The mean values of the colony count for each source were computed. From the results, the number of colonies per $100 \mathrm{~mL}$ for the three (3) water sources ranged from 162 to $209.5 \mathrm{CFU} / 100$ $\mathrm{mL}$. The highest number of colonies was seen in the water obtained from the Okpu stream (209.5CFU/ $100 \mathrm{~mL}$ ) followed by the Ohino stream $(162.5 \mathrm{CFU} / 100 \mathrm{~mL})$, and the least was from Ngwogo stream (162CFU/100 mL (Table 1).

Table 1: Mean bacteria count (CFU/ $100 \mathrm{~mL})$

\begin{tabular}{lll}
\hline Sample sources & $\begin{array}{l}\text { Colony count } \\
(\text { CFU/100 mL) }\end{array}$ \\
\hline 1 & Okpu Stream & 209.5 \\
2 & Ohino Ngodo & 162.5 \\
3 & Ngwogo stream & 162 \\
\hline
\end{tabular}

DOI: http://dx.doi.org/10.4314/ejhs.v27i4.3 
Prevalence of bacterial species: A total of eight (8) bacterial species were isolated and identified. They included Escherichia coli, Pseudomonas aeruginosa., Staphylococcus aureus, Shigella., Klebsiella, Salmonella, Enterococcus and Streptococcus sp. Okpu stream had the least number of isolates 6(23.1\%), while Ngwogo waters had the highest number of isolates
11(42.3\%). The frequency of each isolated organism varied between the different waters as shown in Table 2. E. coli and Staphylococcus spp. had the highest occurrence of $23.1 \%$ from the water samples. It was followed by Klebsiella spp., with prevalence of $15.4 \%$, while the least prevalence of $3.8 \%$ was observed in Salmonella and Streptococcus sp. (Table 2).

Table 2: Prevalence of bacteria isolates from three different water sources

\begin{tabular}{llllll}
\hline S/N & BACTERIA & ON $(\%)$ & $\mathbf{N}(\%)$ & O $(\%)$ & Total isolates $(\%)$ \\
\hline 1 & E. coli & $2(33.3 \%)$ & $2(33.3 \%)$ & $2(33.3 \%)$ & $6(23.1 \%)$ \\
2 & Staphylococcus spp & $2(33.3 \%)$ & $2(33.3 \%)$ & $2(33.3 \%)$ & $6(23.1 \%)$ \\
3 & Streptococcus spp & $0(0 \%)$ & $1(100 \%)$ & $0(0 \%)$ & $1(3.8 \%)$ \\
4 & Klebsiellaspp & $2(50 \%)$ & $2(50 \%)$ & $0(0 \%)$ & $4(15.4 \%)$ \\
5 & Shigellaspp & $2(66.7 \%)$ & $0(0 \%)$ & $1(33.3 \%)$ & $3(11.5 \%)$ \\
6 & Salmonella spp & $0(0 \%)$ & $1(100 \%)$ & $0(0 \%)$ & $1(3.8 \%)$ \\
7 & Pseudomonas spp & $0(0 \%)$ & $2(100 \%)$ & $0(0 \%)$ & $2(7.7 \%)$ \\
8 & Enterobacterspp & $1(33.3 \%)$ & $1(33.3 \%)$ & $1(33.3 \%)$ & $3(11.5 \%)$ \\
\hline & Total & $\mathbf{9 ( 3 4 . 6 \% )}$ & $\mathbf{1 1}(\mathbf{4 2 . 3 \% )}$ & $\mathbf{6 ( 2 3 . 1 \% )}$ & $\mathbf{2 6}(\mathbf{1 0 0 \% )}$ \\
\hline
\end{tabular}

Key: 'ON' = 'Ohino-Ngodo', 'O' = 'Okpu' and 'N' = 'Ngwogo'

Antibiotics susceptibility study: The result of the antibiotics susceptibility study of the isolates showed that all the bacterial isolates exhibited resistance to more than eight (8) antibiotics, although their pattern of resistance varied (Table 3). All isolated organisms were completely resistant to cephalothin, tetracycline, penicillin $\mathrm{G}$, oxytetracycline, cefotaxim and cefuroxime sodium. In addition, the most effective antibiotics were azithromycin and imipenem to which all the isolates were $100 \%$ susceptible to, except in the case of azithromycin, Klebsiella spp. (50\%) susceptible and Shigella spp (67\%), while for imipenem, it was all $50 \%$ susceptible for both Klebsiella spp and Pseudomonas aeruginosa.
Multiple antibiotic resistances were found to be more prominent among Salmonella, Streptococcus, Shigella, and Klebsiella sp. In general, it was inferred that different types of multiple resistance pattern were observed among all the bacterial groups isolated from various points and sources of water (Table 3). 
Table 3: Antibiotic Susceptibility Pattern of Bacteria to Antibiotics

\begin{tabular}{|c|c|c|c|c|c|c|c|c|c|c|c|c|c|c|c|c|c|}
\hline Isolates & T.I & $\overline{\mathrm{AZM}}$ & $\overline{\text { SUL }}$ & $\overline{\text { CEP }}$ & $\overline{\text { SMX }}$ & STR & CPO & CXM & PEN & ERY & $\overline{\text { OXY }}$ & GEN & $\overline{\text { IMP }}$ & NOR & $\overline{\text { CTX }}$ & NAL & $\overline{\text { TET }}$ \\
\hline E. coli & 6 & $6(100)$ & $2(33)$ & $0(0)$ & $0(0)$ & $2(33)$ & $4(67)$ & $0(0)$ & $0(0)$ & $3(50)$ & $0(0)$ & $4(67)$ & $6(100)$ & $3(50)$ & $3(50)$ & $0(0)$ & $0(0)$ \\
\hline Klebsiella spp & 4 & $2(50)$ & $1(25)$ & $0(0)$ & $0(0)$ & $0(0)$ & $2(50)$ & $2(50)$ & $0(0)$ & $1(25)$ & $0(0)$ & $4(100)$ & $2(50)$ & $4(100)$ & $0(0)$ & $0(0)$ & $0(0)$ \\
\hline Shigella spp & 3 & $2(67)$ & $1(33)$ & $0(0)$ & $0(0)$ & $1(33)$ & $0(0)$ & $0(0)$ & $0(0)$ & $2(67)$ & $0(0)$ & $2(67)$ & $3(100)$ & $3(100)$ & $0(0)$ & $0(0)$ & $0(0)$ \\
\hline Salmonella spp & 1 & $1(100)$ & $0(0)$ & $0(0)$ & $0(0)$ & $0(0)$ & $0(0)$ & $0(0)$ & $0(0)$ & $1(100)$ & $0(0)$ & $0(0)$ & $1(100)$ & $1(100)$ & $0(0)$ & $0(0)$ & $0(0)$ \\
\hline $\begin{array}{l}\text { Pseudomonas } \\
\text { spp }\end{array}$ & 2 & $2(100)$ & $1(50)$ & $0(0)$ & $2(100)$ & $0(0)$ & $0(0)$ & $1(50)$ & $0(0)$ & $0(0)$ & $0(0)$ & $1(50)$ & $1(50)$ & $2(100)$ & $0(0)$ & $2(100)$ & $0(0)$ \\
\hline $\begin{array}{l}\text { Enterococcus } \\
\text { spp }\end{array}$ & 3 & $3(100)$ & $2(68)$ & $0(0)$ & $0(0)$ & $2(67)$ & $0(0)$ & $0(0)$ & $0(0)$ & $0(0)$ & $0(0)$ & $1(33)$ & $3(100)$ & $3(100)$ & $1(33)$ & $0(0)$ & $0(0)$ \\
\hline $\begin{array}{l}\text { Staphylococcus } \\
\text { spp }\end{array}$ & 6 & $6(100)$ & $3(50)$ & $0(0)$ & $0(0)$ & $3(50)$ & $3(50)$ & $0(0)$ & $0(0)$ & $3(50)$ & $0(0)$ & $6(100)$ & $6(100)$ & $4(68)$ & $2(33)$ & $0(0)$ & $0(0)$ \\
\hline Streptococcus & 1 & $1(100)$ & $1(100)$ & $0(0)$ & $0(0)$ & $0(0)$ & $0(0)$ & $0(0)$ & $0(0)$ & $0(0)$ & $0(0)$ & $1(100)$ & $1(100)$ & $1(100)$ & $1(100)$ & $0(0)$ & $0(0)$ \\
\hline
\end{tabular}

spp

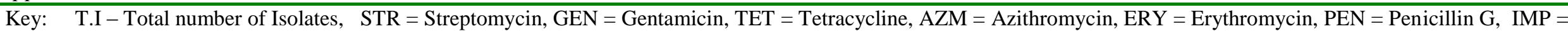

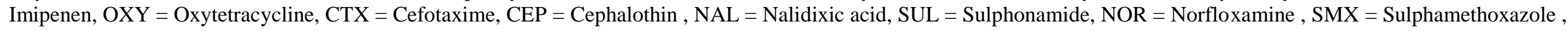
$\mathrm{CXM}=$ Cefuroxime sodium and $\mathrm{CPO}=$ Cefpirome .

Multiple antibiotic resistance indices (MARI): The result from the MARI studies showed that all the organisms had MARI values $>0.20$, with the highest value exhibited by Salmonella spp. (0.75), followed by Streptococcus spp.
(0.63) and Shigella spp. (0.60). The least MARI value was seen in Staphylococcus $\operatorname{spp}(0.44)$ (Table 4) 
Table 4: Multiple Antibiotic Resistance Index (MARI)

\begin{tabular}{llcl}
\hline S/N & ISOLATES & MARI & $\begin{array}{l}\text { ANTIBIOTICS TO WHICH ORGANISMS WERE } \\
\text { RESISTANT TO }\end{array}$ \\
\hline 1 & E. coli & 0.50 & CEP, SXM, CXM, PEN, ERY, OXY, TET, NOR \\
2 & Klebsiella spp & 0.50 & CEP, SXM, CTX, PEN, STR, OXY, TET, NAL \\
3 & Shigella spp & 0.60 & CEP, PEN, CXM, OT, TET, SXM, CPO, CTX, NAL \\
4 & Salmonella spp & 0.75 & CEP, SUL, STR, PEN, CXM, OXY, TET, SXM, CPO, CTX, \\
& & & NAL, CN \\
5 & Pseudomonas & 0.50 & CEP, PEN, STR, OXY, TET, CPO, CTX, ERY \\
& aeruginosa & & \\
6 & Enterobacter spp & 0.56 & CEP, PEN, CXM, TET, SXM, CPO, CTX, NAL, STR \\
7 & Staphylococcus spp & 0.44 & CEP, PEN, CXM, OXY, TET, SXM, NAL
\end{tabular}

Key: STR $=$ Streptomycin, TET $=$ Tetracycline,, ERY $=$ Erythromycin, PEN $=$ Penicillin G, OXY = Oxytetracycline, $\mathrm{CTX}=$ Cefotaxime, $\mathrm{CEP}=$ Cephalothin, $\mathrm{NAL}=$ Nalidixic acid, $\mathrm{SUL}=$ Sulphonamide, $\mathrm{NOR}=$ Norfloxamine, $\mathrm{SXM}$ $=$ Sulphamethoxazole, $\mathrm{CXM}=$ Cefuroxime sodium and $\mathrm{CPO}=$ Cefpirome

\section{DISCCUSION}

In view of the prevailing problem of portable water in Afikpo, the study was conducted to sample some of the surface water used by the population for domestic and drinking purposes. In addition, resistance of microorganisms to antibiotics of clinical interest was previously reported in this area (18). The result of the total bacterial count from the water samples showed very high counts. The bacteriological count ranged from 162209.5CFU/100 mL from the three water sources. These values indicate that the very high microbial load could be attributed to the poor sanitary and hygienic environment of the water. The water constantly receives pollution from surface runoff and seepage from contaminated ground water and waste waters. Some of the surface water is located in a very crowded location and near refuse dumps and pit toilets where they constantly receive doses of fecal materials possibly from pollution from human activity (septic tank, diving), pets, and wild birds.

Various species of bacteria were isolated, most of them belonging to the family Enterobacteriaceae. The bacteria isolated from the waters were Escherichia coli, Pseudomonas aeruginosa, Salmonella, Shigella, Klebsiella, Enterococcus and Streptococcus sp. The presence of faecal coliform like E. coli and Klebsiella in some samples is an indication of recent pollution by sewage. The high coliforms level recorded in this work could be attributed to poor refuse and sewage disposal system, mainly open air disposal method practiced in this area.

These organisms may harbor potential pathogens and the presence of these pathogenic organisms can pose severe health risks to consumers in general and immunocompromised individuals in particular (4). The presence of these pathogenic organisms suggests the presence of other opportunistic and pathogenic bacteria. Thus, the conclusion that the water contains only these eight organisms cannot be drawn, since the study was limited, and results were based only on the samples analyzed. The large number of bacteria was isolated from Ngwogo stream could be the result of high human activities around the environment. Other gram positive bacteria such as Staphylococcus and Streptococcus sp which have been isolated in previous studies were found to be present in Ngwogo stream (19). 
This study revealed the presence of $E$. coli and Staphylococcus spp in all the three water samples analyzed, with prevalence rate of $23.1 \%$ respectively. This is not surprising since presence of $E$. coli in the water sample suggests faecal pollution, hence falls short of the standard of safe drinking water. The high fecal coliform counts obtained from the surface water are not unlikely because the environment in which the majority of the waters are located predisposed them to constant pollution from human and animal waste materials.

Staphylococcus aureus is a common member of the human micro flora. It can produce diseases through two different mechanisms. One is based on the ability of the organisms to multiply and spread widely in tissues, and the other is based on the ability of the organisms to produce extracellular polysaccharides and toxins. Multiplication in tissues can result in manifestations such as boils, skin sepsis, postoperative wound infections, enteric infections, septicaemia, endocarditis, osteomyelitis and pneumonia (20). Gastrointestinal diseases (enterocolitis or food poisoning) is caused by a heat-stable staphylococcal enterotoxin and characterized by projectile vomiting, diarrhoea, fever, abdominal cramps, electrolyte imbalance and loss of fluids.

Klebsiella species poses health risk to patients with impaired immune systems, such as the elderly or very young, patients with burns or excessive wounds, and those undergoing immunosuppressive therapy. Pseudomonas aeruginosa is a recognized cause of hospitalacquired infections with potentially serious complications and has been isolated from a range of moist environments such as sinks, water baths, hot water systems, showers and pools (21). Although the prevalence rate of Pseudomonas is low, the presence of $P$. aeruginosa in drinking water in high volumes may be associated with complaints about taste, odour and turbidity.

The presence of Shigella species was observed from two of the water sources sampled with prevalence rate of $11.5 \%$. Shigella is not particularly stable in water environments; their presence in drinking water indicates recent human faecal pollution (22). Shigella species are enteric pathogens predominantly transmitted by the faecal-oral route through person-to-person contact, contaminated food and water.

The result obtained from this work corroborates some other works that have been carried out previously both in Nigeria and elsewhere. Oyetayo et al., (23) reported 58.3\% prevalence of $E$ coli in water obtained from Akure. Adjuwon et al., (24) reported the presence of E. coli and Aerobacter aerogenes from well water in Ile- Ife, While Oyedeji et al., (25) reported multidrug resistance from bacteria obtained from both streams and well water in IleIfe. Similarly, studies conducted in other parts of the world reported the presence of bacteria especially coliforms from unprotected water bodies such as well and river water sources. For instance, antibiotic resistant bacteria were previously isolated from surface waters such as streams (23). Also, a similar study done in a rural community in Cameroon showed that almost all the waters were contaminated with different types of bacteria including coliforms because they were obtained from unprotected sources (26, 27). Mengesha et al (28) had also reported that $75 \%$ of unprotected well and spring water sources from North Gondar, Ethiopia, were contaminated by faecal coliforms, especially $E$. coli. The presence of these organisms has an implication for public health.

A further objective of this study was to characterize the isolates using their antibiotic resistance profiles. The results revealed that a large proportion of the environmental isolates were resistant to sulphamethaxoid, cephalothin, tetracycline, penicillin G, oxytetracycline, cefotaxim, cefuroxime sodium, nalidixic acid, sulphamethoxazole, erythromycin followed by trimethoprim and amoxicillin. The trend was in accordance with earlier studies that showed resistance towards $\beta$-lactam, macrolides, and phenicols (29).

However, all isolates were highly susceptible to azithromycin, imipenen and norfloxamine. This trend is in line with earlier observations carried out by some researchers (30). Azithromycin has been recommended for the treatment of patients

DOI: http://dx.doi.org/10.4314/ejhs.v27i4.3 
with diarrhea stool. Only few of the isolates such as Pseudomonas, Klebsiella, Salmonella, Streptococcus, Shigella and Enterobacter sp were shown to be resistance to Streptomycin (STR), Erythromycin, Cefotaxim and Cefpirome. All isolates were resistant to Cefuroxime Sodium (CXM); only two of the isolates Klebsella spp and Pseudomonas aeruginosa were susceptible to it.

The result of the multiple antibiotic resistance index showed that Staphylococci spp had the least resistance index (0.44) which could be the result of a low number of isolates resistant to antibiotics or may be due to the efficacy of tested antibiotics against them. The highest MARI of (0.75) was observed among Salmonella spp which could be because higher number of isolates showed resistance against many of the antibiotics used against them. Multiple bacterial resistances to drugs were reported earlier in aquaculture environments (31). Puah et al. (32) reported up to six different resistance patterns, and resistance to at least one antibiotic was seen in 46 isolates (98\%) while multidrug resistance (to two or more drugs) was observed in $93 \%$ of tested isolates. Resistance to multiple antibiotics can lead to occurrence of newly emerging resistant bacteria which may be transmitted to consumers causing infections that are difficult to treat. The relatively high resistance of bacterial pathogens to antibiotics in this study agrees with the findings of Rakic-Martinez et al., (33) who reported the prevalence of MAR bacteria in wastewater. The observed high frequency of bacterial resistance may not only result in the therapeutic failure in the river fauna population, but also endangers the health of the people who are at risk of infection with pathogens from these animals coupled with the possibility of plasmid transfer of resistance to human pathogenic bacteria (34). The prevalence of intrinsic multi-resistance to common antimicrobial agents has been documented $(35,36$, 37, 38, 39, 40, 41, 42).

Antibiotic resistance in bacteria is a serious problem facing society today, and one of the reasons responsible for this problem is overuse of antibiotics in humans (43). According to Sayah et al. (44), the source of water contamination plays a significant role in determining the extent of antimicrobial resistance as contaminating bacteria could come from domestic and wild animals or human sewage. Antibiotic resistance poses a threat to everyone, most especially the children and the immunocompromised ones that are more vulnerable to bacterial illnesses. For the general public, antibiotic resistance limits the number of effective drugs available leading to fewer treatment options for the sick. There is therefore a need to control faecal pollution of water supply to avert the occurrence of waterborne diseases outbreak.

There were limitations the researcher encountered. Some of them are: Water samples were taken over a short period of time and may not have depicted seasonal variation, the number of isolates must have been below the expected number, the study failed to select all antimicrobial agents commonly used for resistance evaluation due to the fact that some of them were not available during the period of study. In conclusion, the study investigated the bacterial profile and antimicrobial resistance pattern of bacteria isolated from selected surface waters in Afikpo. It also demonstrated the occurrence of various bacterial species such as E coli, Pseudomonas, Shigella, Salmonella Klebsella Enterobacter Streptococcus and Staphylococcus sp which was an indication that the water were contaminated with diarrhogenic bacteria. Finally, appropriate measures should be taken to treat surface waters from the study area before usage to prevent the transmission of these pathogenic organisms.

\section{REFERENCES}

1. Faria, C. I., Vaz-moreira, E., Serapicos, O., Nunes C and Manaia, C. M. Antibiotic resistance in coagulase negative staphylococci isolated from wastewater and drinking water. Science of the total environment, 2009; 407(12): 3876 -3882.

2. WHO. Guideline for drinking water quality, vol. 1, world health organization, Geneva, Switzerland, $3^{\text {rd }}$ edition, 2004.

3. Volker, S, Schreiber, C and Kistemann, T "Drinking water quality in household supply

DOI: http://dx.doi.org/10.4314/ejhs.v27i4.3 
infrastructure - a survey of the current situation in Germany," Int. J Hygiene and Env. Health, 2010; 213 (3) : 204-209

4. Biyela P. T., Lin J and Bezuidenhout, C. C. The role of aquatic ecosystem as reservoirs of antibiotic resistance bacteria and antibiotic resistance gene' Water Science and Technology, 2004; 50(1): 45-50

5. Obi, C. L, Potgieter, N, Bessong, P.O andMatsaung, G. Assessment of the microbial quality of river water sources in rural Venda communities in South Africa," Water SA, 2002; 28( 3):287-292

6. Sharma, A., Dubey, N and Sharan, B Characterization of aeromonods isolated from river narmada, India,' International Journal of hygiene and environment using health, 2005; 208:425-428.

7. Chopra, I and Roberts, M. Tetracycline antibiotics: mode of action, applications, molecular biology, and epidemiology of bacterial resistance. Microbiology and Molecular Biology Reviews, 2001; 65:232260.

8. Launay, F. M., Young, P. B., Sterk, S. S., Blokland, M. $\mathrm{H}$ and Kennedy, D. G. Confirmatory assay for zeranol, taleranol and the Fusarium spp. toxins in bovine urine using liquid chromatography-tandem mass spectrometry. Food Additives and Contaminants, 2004; 21(1):52-62.

9. Kim, S., Jensen, J. N., Aga, D. S and Weber A. S. Tetracycline as a selector for resistant bacteria in activated sludge. Chemosphere, 2007; 66(9):1643-1651.

10. Iwane, T., Urase, $\mathrm{T}$ and Yamamoto, $\mathrm{K}$ Possible impact of treated wastewater discharge on incidence of antibiotic resistant bacteria in river water. Water Science and Technology, 2001; 43(2):91-99.

11. Onanuga, A, Igeneghu, $\mathrm{O}$, and Lamikran, $\mathrm{M}$. A study of the prevalence of diarrhoeagenic Escherichia coli in children from Gwagwalada, Federal Capital Territory,Nigera Pan African. Medical Journal, 2014; 17:146

12. Bryce, J., Walker, N., Black, R.E., Bhuutta, N.W., Lawn, J. E and Steketee R. W. Can the world afford to save the lives of 6 million children each year? The Lancet, 2005; 365(9478), 1541-1547.

13. Toma, C., L.u, Y., Higa, N., Nakasone, N., Chinen, I., Baschkier, A., Rivas, $\mathrm{M}$ and Iwanaga, M. Multiplex PCR assay for identification of human diarrheagenic Escherichia coli. Journal of Clinical Microbiology, 2003;.41: 2669-2671.

14. Garcia_an-Barcia, M. P., Alvarado, A and De la Cruz, F. Identification of bacterial plasmids based on mobility and plasmid population biology.FEMS Microbiology Review; 2011

15. SANS: South African National Standards, "Drinking water- part 1: microbiological, physical, chemical, aesthetic and chemical determinands," SABS Standards Division, Pretoria, South Africa, 2011

16. Committee for Clinical Laboratory Standards Performance standards for antimicrobial disk susceptibility tests. 7th ed. NCCLS document M2-M7, 2000.

17. Riaz, S., Faisal, M. and Hasnain, S. Antibiotic susceptibility pattern and multiple antibiotic resistances (MAR) calculation of extended spectrum $\beta$-lactamase (ESBL) producing Escherichia coli and Klebsiellaspp. in Pakistan. African Journal of Biotechnology, 2011; 10(33):6325-6331.

18. Onuoha, S.C. Antibiotic susceptibility pattern of Escherichia coli isolated from well water in Afikpo,SouthEasthern, Nigeria. AASCIT Journal of Biology, 2015; 1(3): 38-42.

19. Lateef, A. The microbiology of a pharmaceutical effluent and its public health implications. World Journal of Microbiology and Biotechnology, 2004; 20: 167-171.

20. World Health Organization. Guidelines for Drinking-Water Quality. 4th ed., NLM Classification: WA 675, World Health Organization, Geneva, Switzerland,: 307-433, 2011.

21. De Victorica, J and Galván, M. Pseudomonas aeruginosa as an indicator of health risk in water for human consumption. Water Science. Technology., 2001; 43, 49-52.

22. Alamanos, et al. A community waterborne outbreak of gastro-enteritis attributed to 
Shigella sonnei. Epidemiology and Infection, 2000;125, 499-503.

23. Oyetayo VO, Akharaiyi FC, Oghumah M Antibiotic Sensitivity Pattern of Escherichia coli Isolated from Water Obtained from Wells in Akure Metropolis. Research Journal . Microbiology, 2007; 2(2): 190-193.

24. Adejuwon, A. O., Bisi-Johnson, M.A., Agboola, A.O., Fadeyi, B.O \&Adejuwon, A.O Antibiotic sensitivity patterns of Escherichia c oli and Aerobacter aerogenes isolated from well water in IIe- Ife, Nigeria. International Journal Medicine \& Medical Sciences, 2011; 3(5): 155-160.

25. Oyedeji O, Olutiola PO, Moninuola M.A Microbiological quality of packaged drinking water brands marketed in Ibadan metropolis and Ile Ife city in South Western Nigeria. Afr. Journal Microbiological. Research. 2010; 4(1): 096- 102.

26. Abera, A.B, Emire, S.A and Ayele, A .K . The prevalence of antibiotic-resistant Escherichia coli isolates from fecal and water sources. Academia Journal. Micro. Research , 2013; 1(1): 001-010.

27. Kuitcha, D., Josephine, N., Margareth, T., Kamgang, L., Veronique, k., Henriette, A \& Emmanuel., E. Bacterial contamination of water point of the upper Mfoundi watershed, yaounde, Cameroon, Afr J. Microbiol, Res, 2010; 4(7): 568-574

28. Mengesh, A., Mamo. W \&Baye, G. A survey of bacteriological quality of drinking water in North Gondar.Ethiopian J. Health Dev, 2004; 18(2): 112-115.

29. Mulamattathil, S.G, Benzudenhout, C, Mbewe, $\mathrm{M}$ and Ateba, C.N. Isolation of environmental bacteria from surface and drinking water in Mafinkeng, South Africa, and characterization using their Antibiotic resistance Profile. Journal of Pathogens, 2014

30. Lin, J, Biyela, P and Puckree, T "Antibiotic resistance profiles of environmental isolates from Mhlathuze River, KwaZulu- Natal (RSA)," Water SA, 2004; 30(1), 23-28

31. Hatha, M., Viverkanandam, A.A., Joice, G.J., Chistol, G.J. Antibiotic resistance patterns of mobile aeromonds from farm raised fresh fish. Int. J. Food Microbiol. , 2005; 98, 131-134.

32. Puah, S., Puthucheary, S.D., Liew, F., Chua, $\mathrm{K}$. Aeromonas aquariorum clinical isolates: antimicrobial profiles, plasmids and genetic determinants. Int. J. Antimicrob. Agents, 2013; 41, $281-284$

33. Rakic-Martinez, M., Drevets, D.A., Dutta, V., Katic, V., Kathariou, S., Listeria monocytogenes strains selected on ciprofloxacin or the disinfectant benzalkonium chloride exhibit reduced susceptibility to ciprofloxacin, gentamicin, benzalkonium chloride, and other toxic compounds. Appl. Environ. Microbiol, 2011; 77, 8714-8721.

34. Schmidit, A.S., Bruun, M.S., Dalsgaard, I., Larsen, J.L. Incidence distribution and spread of tetracycline resistance determinant and integrons-associated antibiotic resistance gene among motile aeromonds from a fish-farming environment.Appl. Environ. Microbiol., 2001; 67, 5675-5682.

35. Wright, G.D. The antibiotic resistome: the nexus of chemical and genetic diversity. Nat. Rev. Microbiol. 2007; 5:175-186.

36. Baltz, R.H. Renaissance in antibacterial discovery from actinomycetes.Curr.Opin .Pharmacol, 2008; 8, 557-563.

37. Brown, M.G., Balkwill, D.L Antibiotic resistance in bacteria isolated from the deep terrestrial subsurface. Microb.Ecol, 2009; 57,484-493.

38. Thaller, M.C., Migliore, L., Marquez, C., Tapia, W., Cedeno, V. Tracking acquired antibiotic resistance in commensal bacteria of Galapagos land iguanas: no man, no resistance. PLoS One, 2010; 5, e8989

39. Toth, M., Smith, C., Frase, H., Mobashery, S., Vakulenko, S. An antibiotic resistance enzyme from a deep-sea bacterium.J. Am. Chem. Soc. , 2010; 132, 816-823.

40. D’Costa, V.M., King, C.E., Kalan, L., Morar, M., Sung, W.L. Antibiotic resistance is ancient. Nature, 2011; 477: 457-461.

41. Bhullar, K., Waglechner, N., Pawlowski, A., Koteva, K., Banks, E.D., Johnston, M.D., Barton, H.A., Wright, G.D. Antibiotic

DOI: http://dx.doi.org/10.4314/ejhs.v27i4.3 
resistance is prevalent in an isolated cave microbiome. PLoS One, 2012; 7: 34953

42. Cox, G., Wright, G.D. Intrinsic antibiotic resistance: mechanisms, origin, challenges and solutions. Int. J. Med. Microbiol, 2013; 303, 287-292.

43. Okeke IN, Abiodun O. A, Byarugaba DK, Ojo KK, Opintan J. A Growing problem of multidrug-resistant enteric pathogens in Africa.Emerg. Infect. Dis, 2007; 13(11): 16401646.

44. Sayah RS, Kaneene JB, Johnson Y, Miller RA Patterns of antimicrobial resistance observed in Escherichia coli isolates obtained from domestic-, wild-animal fecal samples, human septage, and surface water. Appl. Environ. Microbiol., 2005, 71(3): 1394-1404. 